\author{
Daniela Brzóska \\ Koło Naukowe Infologów \\ Instytut Bibliotekoznawstwa i Informacji Naukowej \\ Uniwersytet Śląski w Katowicach \\ e-mail: daniela.brzoska97@gmail.com \\ (D) https://orcid.org/0000-0002-6772-3399
}

\title{
Sprawozdanie z działalności \\ Koła Naukowego Infologów \\ przy Instytucie Bibliotekoznawstwa \\ i Informacji Naukowej \\ Uniwersytetu Śląskiego w Katowicach w 2018 r.
}

W roku 2018 działalność członków Koła Naukowego Infologów (dalej: KNI), działającego przy Instytucie Bibliotekoznawstwa i Informacji Naukowej Uniwersytetu Śląskiego w Katowicach, przejawiała się w kilku obszarach: publikacyjnym, konferencyjnym (uczestnictwo w spotkaniach o tematyce bibliotekoznawczej i informatologicznej) oraz organizacyjnym.

Studenci zrzeszeni w KNI ogłosili 11 tekstów, które można podzielić na dwie kategorie: artykuły i sprawozdania z wydarzeń, głównie regionalnych, w których brali udział. Wszystkie materiały ukazały się w kwartalniku wydawanym przez macierzysty Instytut Bibliotekoznawstwa i Informacji Naukowej - „Nowa Biblioteka. Usługi, Technologie Informacyjne i Media".

W numerze 2 (29) został opublikowany artykuł Karoliny Żuk, zatytułowany Analiza bibliometryczna publikacji członków Koła Naukowego Bibliotekoznawców przy Instytucie Bibliotekoznawstwa i Informacji Naukowej Uniwersytetu Ślaskiego w Katowicach (2007-2016) (s. 109-121). Autorka zanalizowała publikacje członków Koła, by ukazać cechy działalności naukowej studentów, w tym zjawisko autorstwa i wieloautorstwa występującego w analizowanych materiałach, typy wypowiedzi, 
tematykę. Omówiła również tendencje wzrostowe i spadkowe liczby ogłoszonych tekstów.

W numerze 3 (30) zamieszczony został artykuł Nikolety Saluk Funkcje książek i prasy regionalnej w sieci. Studium przypadku (s. 73-83). Autorka przedstawiła sposoby oddziaływania publikacji regionalnych, mediów i prasy na społeczności lokalne. Zwróciła uwagę na rolę internetu w procesie poszerzania zakresu ich działania. Opisała podstawowe cele mediów lokalnych i wskazała szanse, jakie daje przestrzeń sieciowa, która nie jest równoznaczna z zagrożeniem dla książek i gazet $\mathrm{w}$ tradycyjnej formie. Nowoczesne rozwiązania pozytywnie wpływają za to na lepszy odbiór publikacji przez potencjalnych czytelników.

W tym samym numerze czasopisma swój artykuł pt. Źródła informacji w pracy nauczyciela regionalisty (na przykładzie Gimnazjum nr 9 w Bytomiu) ogłosiła Adriana Piechota (s. 117-135). Autorka, prowadząc badania w trzech etapach: wywiadu jawnego, analizy dokumentów, czyli kronik klas regionalnych, oraz wykorzystania kwestionariuszy ankiet, zidentyfikowała źródła informacji, z jakich korzystają nauczyciele regionaliści uczący w Gimnazjum nr 9 w Bytomiu. Były to przede wszystkim książki, filmy i strony internetowe zawierające informacje o regionie.

W numerze 4 (31) został opublikowany artykuł Wojciecha Balawendera pt. Sita haset w kontekście ochrony zbiorów danych (s. 37-50). Autor porównał jakość haseł chroniących zasoby komputerowe za pomocą entropii informacyjnej. Omówił kluczowe regulacje prawne obowiązujące administratorów baz danych oraz wybrane metody przechwytywania i łamania haseł.

Większą grupę materiałów przygotowanych przez członków KNI stanowią sprawozdania. Pod koniec roku 2017 wzięli oni udział w trzech wydarzeniach, które następnie opisali w numerze 2 (29) kwartalnika. Dominika Panek przedstawiła relację z seminarium naukowego „Biblioteki Europy" (s. 145-152), zorganizowanego 8 listopada przez Instytut Bibliotekoznawstwa i Informacji Naukowej Uniwersytetu Śląskiego w Katowicach. Zuzanna Świeżowska ogłosiła sprawozdanie z obchodzonego 20 listopada jubileuszu pracy naukowej i dydaktycznej Profesor Ireny Sochy (s. 109-121). Wydarzenie zgromadziło przyjaciół, współpracowników i studentów Jubilatki oraz przedstawicieli wielu ośrodków naukowych w Polsce. Z kolei Martyna Król i Katarzyna Szmidt scharakteryzowały XI Ogólnopolską Studencko-Doktorancką Konferencję Kół Naukowych Bibliotekoznawców „Ochrona i bezpieczeństwo zasobów archiwalnych, bibliotecznych, muzealnych, galerii i innych instytucji kultury i nauki - dawniej i dziś" z 5 grudnia (s. 173-177). Wydarzenie to zostało zorganizowane przez KNI. 
W roku 2018 miesiącem obfitującym w różnego typu spotkania był maj. Monika Matysik i Magdalena Mientus opisały obrady zorganizowanej 15 maja w Sali Parnassos Biblioteki Śląskiej w Katowicach konferencji pod hasłem „Odmiany wolności w życiu i twórczości Zofii Kossak”. W setną rocznicę odzyskania przez Polskę niepodległości i pięćdziesiątą rocznicę śmierci pisarki (numer 3(30), s. 241-244). Wydarzenie zostało przygotowane przez książnicę i Katolickie Stowarzyszenie „Civitas Christiana”. 21 maja Daniela Brzóska, Elena Drobitko, Daniel Arndt, Adam Gajecki i Kamil Nowak wzięli udział w odbywającym się w Krakowskim Parku Technologicznym Uniwersytetu Jagiellońskiego w Krakowie III Warsztacie Pracy Infobrokera - WPI 3.0. D. Brzóska opisała następnie jego przebieg w numerze 4 (31), s. 155-157. Trzeba wspomnieć, że spotkanie zostało przygotowane przez Stowarzyszenie Profesjonalistów Informacji oraz Uniwersytet Jagielloński w Krakowie. Studenci z KNI mogli poznać kulisy pracy praktyków informacji, w szczególności zajmujących się infobrokerstwem. M. Król i K. Szmidt opublikowały natomiast sprawozdanie z konferencji „Książka i biblioteki na przestrzeni wieków”, zorganizowanej 23 maja przez Instytut Bibliotekoznawstwa i Informacji Naukowej Uniwersytetu Śląskiego w Katowicach oraz Centrum Informacji Naukowej i Bibliotekę Akademicką w Katowicach (nr 4 (31), s. 159-163). Tematami przewodnimi wydarzenia były: sposoby przechowywania zasobów bibliotecznych, historia bibliotek i czasopism, a także działalność zakładów introligatorskich.

Należy też wspomnieć o podsumowującym działalność KNI w roku 2017 sprawozdaniu K. Żuk, zamieszczonym w numerze 3 (30) kwartalnika (s. 245-249).

Przedstawiciele KNI aktywnie uczestniczą w ruchu naukowym poprzez udział w ogólnopolskich konferencjach. W 2018 r., w trakcie wspomnianej już konferencji „Książka i biblioteki na przestrzeni wieków", Bartłomiej Legis wygłosił prelekcję Idee, które przetrwaty 400 lat - sir Thomas Boodley i dzieje Biblioteki Bodlejańskiej. Podczas zorganizowanego w dniach 15-17 maja VII Kongresu Kół Naukowych Uniwersytetu im. Adama Mickiewicza w Poznaniu pod hasłem „100-lecie odzyskania niepodległości. Bilans i perspektywy” A. Piechota i Z. Świeżowska przedstawiły referat Druki polskie na Ślasku $w$ dwudziestoleciu międzywojennym a powrót Ślaska do macierzy. W zorganizowanej 20 listopada XII Ogólnopolskiej Studencko-Doktoranckiej Konferencji Kół Naukowych Bibliotekoznawców „Ludzie, idee, instytucje w przestrzeni biblioteczno-edukacyjnej" referaty wygłosiło czworo członków KNI: Joanna Balawender i D. Panek (Czego 
oczekuja IBiINowicze? Prezentacja wyników ankiety badajacej potrzeby studentów Instytutu Bibliotekoznawstwa i Informacji Naukowej Uniwersytetu Śląskiego w Katowicach); K. Żuk (Czytelnictwo uczniów szkót podstawowych: wyniki badań przeprowadzonych wśród uczniów klas szóstych) oraz A. Gajecki (Edukacja międzykulturowa w polskiej szkole na przykladzie województwa podlaskiego).

5 września 2018 r. A. Piechota wzięła udział w Konferencji Federacji Bibliotek Kościelnych FIDES, zorganizowanej przez Sekcję Bibliotek Szkół Wyższych Stowarzyszenia Bibliotekarzy Polskich przy Zarządzie Okręgu w Katowicach oraz Bibliotekę Teologiczną Uniwersytetu Śląskiego w Katowicach. Tematyka spotkania obejmowała: RODO, informatyczne narzędzia zarządzania informacją własną oraz prezentacje wyników badań językoznawczych. 25 września N. Saluk uczestniczyła w XLI Forum Sekcji Bibliotek Szkół Wyższych Stowarzyszenia Bibliotekarzy Polskich przy Zarządzie Okręgu w Katowicach pt. „Sytuacja bibliotek i bibliotekarzy w kontekście zmieniającego się prawa". $\mathrm{Na}$ spotkaniu analizowano problemy prawne w zakresie wykonywania zawodu bibliotekarza w momencie wdrażania nowej ustawy o szkolnictwie wyższym. 24 października A. Piechota wzięła udział w konferencji „Sztuka czytania - sztuka książki” przygotowanej przez Miejską Bibliotekę Publiczną w Gliwicach. Obrady odbywały się w Centrum Edukacyjnym im. św. Jana Pawła II w Gliwicach. Celem wydarzenia była wymiana wiedzy i doświadczeń specjalistów, przedstawicieli różnych ośrodków akademickich oraz osób zawodowo związanych ze sztuką książki. 25 października M. Król i K. Szmidt wzięły udział w seminarium ,Książka na piątkę, znakomity początek: rozdanie drugie" zorganizowanym przez Miejską Bibliotekę Publiczną im. Jerzego Fusieckiego w Zabrzu, Centrum Kształcenia Praktycznego i Ustawicznego w Zabrzu oraz Pedagogiczną Bibliotekę Wojewódzką im. Józefa Lompy w Katowicach filia w Zabrzu.

Ostatni obszar działalności KNI dotyczy organizacji i współorganizacji różnego typu wydarzeń związanych przede wszystkim z promocją Uniwersytetu Śląskiego w Katowicach, macierzystego Instytutu oraz samego Koła. Najważniejszym wydarzeniem jest organizowana cyklicznie Ogólnopolska Studencko-Doktorancka Konferencja Kół Naukowych Bibliotekoznawców. 20 listopada 2018 r. odbyła się pod hasłem „Ludzie, idee, instytucje w przestrzeni biblioteczno-edukacyjnej” jako dwunasta edycja wydarzenia. Została podzielona na cztery sesje tematyczne: instytucje w przestrzeni biblioteczno-edukacyjnej; czytelnik i kultura czytelnicza; konteksty i prognozy przestrzeni biblioteczno-edukacyjnej; użytkownicy instytucji bibliotecznych i edukacyjnych. W wydarzeniu 
wzięło udział ponad stu słuchaczy oraz osiemnastu prelegentów reprezentujących wiele ośrodków w kraju ${ }^{1}$.

Członkowie KNI uczestniczyli także w Studenckim Festiwalu Nauki, zorganizowanym przez Uniwersytet Śląski w dniach 24-26 kwietnia 2018 r. Przygotowali wówczas warsztaty polegające na przygotowywaniu zakładek, etui z filcu, quillingu. Członkini KNI uczyła zebranych sztuki tworzenia inicjałów, natomiast D. Arndt, A. Gajecki i K. Nowak przedstawili prezentację z zakresu informacji naukowej i przeprowadzili test wiedzy z nagrodami dla uczestników. Zajęcia te cieszyły się dużym zainteresowaniem dzieci i młodzieży oraz ich opiekunów.

Plany KNI na przyszły rok obejmują publikowanie artykułów i sprawozdań oraz organizację cyklicznej ogólnopolskiej studencko-doktoranckiej konferencji pod hasłem „Specjalna, specjalny, specjalne biblioteka, użytkownik, usługi”.

Tekst $w$ wersji poprawionej wptynat do redakcji 6 marca 2019 r.

${ }^{1}$ Biblioteka Politechniki Wrocławskiej, Biblioteka Zespołu Szkół Handlowych im. Bolesława Prusa w Katowicach, Miejski Ośrodek Pomocy Społecznej w Katowicach, Miejsko-Powiatowa Biblioteka Publiczna w Pszczynie, Pedagogiczna Biblioteka Wojewódzka im. Józefa Lompy w Katowicach, Powiatowa i Miejska Biblioteka Publiczna „Biblioteka pod Atlantami” w Wałbrzychu, Publiczna Biblioteka Pedagogiczna RODN „WOM” w Częstochowie, Uniwersytet Mikołaja Kopernika w Toruniu, Uniwersytet Śląski w Katowicach, Stowarzyszenie Wspierania Organizacji Pozarządowych MOST, Szkoła Podstawowa nr 4 im. Juliana Tuwima w Sosnowcu. 